\title{
Quality of life of patients receiving a single or combination of calcium channel blocker-angiotensin receptor blocker: A cross-sectional study in West Java, Indonesia
}

\author{
Juwita Ramadhani $^{1}$, Mutakin Mutakin ${ }^{2}$, Dyah Aryani Perwitasari ${ }^{3}$, Jutti Levita ${ }^{1^{*}}$ \\ ${ }^{1}$ Department of Pharmacology and Clinical Pharmacy, Faculty of Pharmacy, Universitas Padjadjaran, Sumedang 45363, Indonesia. \\ ${ }^{2}$ Department of Pharmaceutical Analysis and Medicinal Chemistry, Faculty of Pharmacy, Universitas Padjadjaran, Sumedang 45363, Indonesia. \\ ${ }^{3}$ Faculty of Pharmacy, Universitas Ahmad Dahlan, Yogyakarta 55166 Indonesia.
}

\begin{tabular}{l}
\hline ARTICLE INFO \\
\hline Received on: 09/10/2019 \\
Accepted on: 04/01/2020 \\
Available online: 05/03/2020 \\
\hline Key words: \\
Angiotensin receptor blocker, \\
calcium channel blocker, \\
hypertension, quality of life.
\end{tabular}

\section{INTRODUCTION}

Hypertension is the third cause of death in Indonesia, and the prevalence of hypertension, based on the Indonesian Basic Health Research 2018, was $34.1 \%$ (Ministry of Health of the Republic of Indonesia, 2019). The 8th Joint National Committee described that hypertension can be treated by either a single therapy or a combination. The first drugs of choice are calcium channel blocker $(\mathrm{CCB})$, diuretics, angiotensin-converting enzyme inhibitors (ACEi), and angiotensin receptor blocker (ARB). ACEi is rarely used due to its intolerance, e.g., dry cough, fatigue,

\section{"Corresponding Author}

Jutti Levita, Department of Pharmacology and Clinical Pharmacy, Faculty of Pharmacy, Universitas Padjadjaran, Sumedang 45363, Indonesia. E-mail: jutti.levita@unpad.ac.id headache, and sudden drop of blood pressure. ARB, however, is the best choice as a single therapy or in combination (Abraham et al., 2015). The use of CCB, which had been proven to be related to the prevention of cardiovascular disease, as compared to ARB, resulted that $\mathrm{CCB}$ therapy showed the better outcomes than ARB (Black, 2004; Wu et al., 2014). However, both the CCB and ARB indicated similar effects on mortality and heart failure (Wu et al., 2014).

The treatment of hypertension should be safe and does not interfere with the quality of life $(\mathrm{QoL})$ of the patients (Fletcher, 1999). Based on the trials of hypertension prevention and the treatment of mild hypertension, it was shown that a decrease in blood pressure was directly proportional to the improvement of the QoL (Batey et al., 2000; Grimm et al., 1997). The QoL can be determined by assessing the physical, mental, and social welfare conditions of the patients using the Euroqol 5 dimensions 5 levels (EQ5D5L) and Euroqol visual analog scale (EQVAS) (EQVAS/patient's self-health assessment). EQ5D5L is a generic 
and general instrument that aims to measure, compare, and assess health status in all the types of diseases (Devlin and Brooks, 2017). It includes five dimensions: mobility, self-care, normal activity, pain/discomfort, and anxiety/depression. Each dimension has five levels: no problems, few problems, moderate problems, severe problems, and extreme problems (Herdman et al., 2011). These assessments can help to manage therapy in patients with chronic conditions and contribute to an evaluation of primary care services (Bakas et al., 2012; Hand, 2016).

This cross-sectional study was conducted to determine the QoL of the hypertensive outpatients treated with a single therapy of $\mathrm{CCB}$ and combination of $\mathrm{CCB}$ and $\mathrm{ARB}$ at a primary referral hospital in West Java, Indonesia. Measurement was conducted using the validated-EQ5D5L and EQVAS questionnaire from December 2018 to February 2019.

\section{MATERIALS AND METHODS}

\section{Design}

A cross-sectional study was performed on adult hypertensive outpatients (aged 18-60 years) at a primary referral hospital in West Java, Indonesia. Inclusion criteria were as follows: 1) patients were diagnosed with code ICD10-CM-I10 (ICD-10 is a specific code for primary hypertensive patients who do not have comorbid heart or kidney disease) (Beckman, 2014), 2) patients were treated with $\mathrm{ARB}$ and/or CCB either in single therapy or in combination for more than 6 months, 3) patients agreed to participate in this study by signing the informed consent, and 4) patients did not suffer more than one comorbid disease. Exclusion criteria were as follows: 1) patients did not continue their health control or did not respond to the scheduled-health control and 2) patients passed away during the study.

\section{Patients}

Participants were 83 hypertensive outpatients, comprised of 59 female and 24 male. The minimum sample size was calculated using an unpaired categorical equation:

$$
n_{1}=n_{2}=\left(\frac{Z_{\alpha} \sqrt{2 P Q}+Z_{\beta} \sqrt{P_{1} Q_{1}+P_{2} Q_{2}}}{P_{1}-P_{2}}\right)^{2}
$$

with a type 1 error value of $5 \%\left(Z_{\alpha}=1.96\right)$ and type 2 error value of $20 \%\left(Z_{\beta}=0.84\right)$, and the precision of the previous study was 0.24 as described previously (Sari, 2017).

The calculation resulted in $\mathrm{n}=\left(\frac{1.36+0.54}{0.4}\right)^{2}=22.56 \approx$ or minimum sample size of 23 patients.

All 83 outpatients, who had received antihypertensive drugs for $20 \pm 3.3$ months, were included in this study.

\section{Ethics statement}

The study had been approved by the Hospital Ethics Committee (approval document No. 445/065/TKEP/2018) and was conducted in accordance with this ethical consideration. The patients' privacy, confidentiality, and security were maintained for limited access only. An informed consent had been signed before the study was conducted.

\section{QoL instrument}

The QoL was assessed using the EQ5D5L and EQVAS (visual analog scale/patient's self-health assessment). This instrument had been validated (Setiawan et al., 2018), tested, and retested for its Indonesian version (Staff, 2018) and resulted from available value sets (Purba et al., 2017). Higher scores indicate a better HRQoL.

\section{Statistical analysis}

Patients' demographic information (e.g., blood pressure, age, sex, education level, occupation, marital status, ethnicity, tea and/or coffee consumption and smoking, physical activity, comorbidities, and daily antihypertension drugs that were taken) was analyzed using the descriptive analysis. The bivariate analysis was used to see the relationship between the independent and dependent variables. The level of significance used was $5 \%$ ( $\mathrm{p} \leq 0.05$ means that there is a correlation between the two variables) followed by multivariate analysis, e.g., multiple logistic regression analysis for categorical independent variables and two categorical dependent variables. All analyses were carried out using the SPSS version 22.0 (SPSS Inc., Chicago, IL).

\section{RESULTS AND DISCUSSION}

The age of the patients was $51 \pm 1.04$ years, $59(71.3 \%)$ were female, $70(84.3 \%)$ were married, and $55(66.2 \%)$ never undertook physical activity. Daily drugs consumed were $4 \pm$ 0.19 items and the length of hypertensive treatment was $20 \pm$ 3.3 months. Majority of the patients were Muslims (95.2\%). The lowest QoL belongs to hypertensive patients with primary education level. These patients show a limited knowledge about the antihypertensive drugs, and some of them even admitted that they sometimes forget to take their medication. The result was compared with that of Skevington, who studied cross-cultural data taken from 9,404 sick and well adults in 13 countries. This author reported that there was a positive and sequential increase of environmental QoL from no education to tertiary education. The patients with higher educational level indicated better feelings, less dependence on medication and treatment, and positive perceptions of financial resources (Skevington, 2010).

Moreover, $42.2 \%$ of the patients routinely drink tea and/or coffee (two cups or more daily). This habit might have no relevant connection with the QoL of the patient; nonetheless, a recent study on 335 hypertensive Chinese patients in Nanjing, China, suggested that selecting green tea or limiting tea consumption might reduce the risk of hyperhomocysteine in the hypertensive patients (Zhu et al., 2019). Another recent study reported that a higher consumption of green tea ( $>3$ cups/day) was inversely associated with stroke risk in middle-aged and older Korean men (Lee and Kim, 2019).

About $38.55 \%$ of the hypertensive patients indicated slight problems in the area of pain/discomfort and anxiety/ depression. The highest percentage of a moderate problem $(25.30 \%)$ and severe problem $(9.64 \%)$ was found in the area of pain/discomfort (Table 1), which is similar to the previous studies (Bardage and Isacson, 2001; Zhang et al., 2017).

The patients participated in this study never had the time to do standard physical activity (3 times/week at 30 minutes). 
Table 1. QoL measurements of the patients.

\begin{tabular}{lccccc}
\hline EQ5D5L & Mobility & Self-care & $\begin{array}{c}\text { Difficulty in doing } \\
\text { the usual activity }\end{array}$ & $\begin{array}{c}\text { Pain/ } \\
\text { Discomfort }\end{array}$ & $\begin{array}{c}\text { Anxiety/ } \\
\text { Depression }\end{array}$ \\
\hline No problem & 45 & 64 & 39 & 20 & 26 \\
Slight problem & 19 & 6 & 25 & 32 & 32 \\
Moderate problem & 12 & 9 & 14 & 21 & 18 \\
Severe problem & 5 & 2 & 3 & 8 & 7 \\
Extreme problem & 2 & 2 & 2 & 2 & 2 \\
\hline
\end{tabular}

Most of these patients $(72.3 \%)$ are unemployed or housewives with a comorbid disease (stroke). This study also proved that there is a significant relationship between physical exercise and the QoL of the patients.

Physical activity was suggested to improve the wellness of the patients with stroke (Kim et al., 2016). Physical activity was reported to positively correlate with the adult HRQoL domains of 1,100 respondents in Brasov, Romania (Bădicu, 2018). Another study of Oza and coworkers concluded that the determinants of the QoL for the hypertensive patients were age, female gender, duration, number of symptoms, systolic blood pressure, and number of medication (Oza et al., 2014).

Table 2 shows that EQVAS score on exercise $(p<0.05)$ indicated a correlation between the patients' exercise activity (defined by 30 minutes exercise 3 times/week) and the QoL of the patient. Moreover, Pearson correlation shows that the EQ5D5L score is positively related to EQVAS with a moderate degree of correlation (Sig. 0.469).

Of the 83 hypertensive participants, 37 patients (44.6\%) were being treated with a single CCB, whereas 46 patients (55.4\%) were being given the combination of $\mathrm{CCB}$ and $\mathrm{ARB}$. Table 3 indicates that the best QoL (EQ5D5L score) was found in patients treated with a combination of nifedipine and candesartan (EQ5D5L score $=0.83 \pm 0.04)$ which correlates with the patient's self-health assessment (EQVAS score $0.75 \pm 0.06$ ). Meanwhile, patients treated with a single CCB (either amlodipine EQ5D5L score $=0.51 \pm 0.08$ or nifedipine EQ5D5L score $=0.38 \pm 0.53$ ) indicated a lower score. Candesartan cilexetil is an angiotensin II type 1 receptor antagonist (ARB) that inhibits the actions of angiotensin II on the renin-angiotensin-aldosterone system. Oral candesartan of 8-32 $\mathrm{mg}$ once daily is recommended for the treatment of adult hypertensive patients (Cernes et al., 2011). A comparative study on the effect of candesartan versus telmisartan or valsartan had been carried out. 227 patients were grouped and treated with $40 \mathrm{mg}$ telmisartan $(n=74), 8 \mathrm{mg}$ candesartan cilexetil $(n=79)$, or $80 \mathrm{mg}$ valsartan $(n=74)$ for 3 months. Results showed that both the systolic and diastolic blood pressures of all the groups significantly decreased at the end of the study; the decrease was comparable among the three groups (Ozaki et al., 2010).

Nonetheless, the presence of comorbidities in this study lowers the QoL of hypertensive patients. Some of the patients need a walking aid, particularly those who suffer from hemorrhagic stroke.

Comorbidities, e.g., stroke (Oza et al., 2014), Parkinson's (Valkovic et al., 2015), epilepsy (Izci et al., 2016), end-stage renal disease (ESRD) (Lee et al., 2015), and osteoporosis (BarcenillaWong et al., 2015), which affected the QoL of the patients had been reported in other studies. The hypertensive patients with complicated illnesses resulted in a lower QoL were also reported (Zhang et al., 2017).
Table 2. EQ5D5L and EQVAS score in the hypertensive patients.

\begin{tabular}{|c|c|c|c|c|}
\hline \multirow{2}{*}{ Characteristics } & \multicolumn{2}{|c|}{ EQ5D5L } & \multicolumn{2}{|c|}{ EQVAS } \\
\hline & Mean & $p$-value & Mean & $p$-value \\
\hline \multicolumn{5}{|l|}{ Sex } \\
\hline Male & $0.53 \pm 0.08$ & 0.25 & $0.65 \pm 0.03$ & 0.10 \\
\hline Female & $0.57 \pm 0.06$ & & $0.72 \pm 0.02$ & \\
\hline \multicolumn{5}{|l|}{ Age } \\
\hline$<50$ & $0.59 \pm 0.07$ & 0.80 & $0.69 \pm 0.03$ & 0.74 \\
\hline$\geq 50$ & $0.54 \pm 0.07$ & & $0.71 \pm 0.02$ & \\
\hline \multicolumn{5}{|l|}{ Level of education } \\
\hline High & $0.66 \pm 0.05$ & 0.06 & $0.71 \pm 0.02$ & 0.61 \\
\hline Low & $0.46 \pm 0.08$ & & $0.69 \pm 0.03$ & \\
\hline \multicolumn{5}{|l|}{ Occupation } \\
\hline Employed & $0.57 \pm 0.06$ & 0.56 & $0.69 \pm 0.03$ & 0.73 \\
\hline Unemployed & $0.53 \pm 0.09$ & & $0.71 \pm 0.02$ & \\
\hline \multicolumn{5}{|l|}{ Marital status } \\
\hline Married & $0.55 \pm 0.05$ & 0.96 & $0.7 \pm 0.01$ & 0.86 \\
\hline Single/divorced & $0.61 \pm 0.10$ & & $0.7 \pm 0.03$ & \\
\hline \multicolumn{5}{|l|}{ Caffeine intake } \\
\hline Coffee/tea & $0.61 \pm 0.43$ & 0.09 & $0.7 \pm 0.14$ & 0.65 \\
\hline Never & $0.47 \pm 0.08$ & & $0.69 \pm 0.02$ & \\
\hline \multicolumn{5}{|l|}{ Smoking status } \\
\hline Current/ex-smoker & $0.54 \pm 0.09$ & 0.18 & $67.00 \pm 2.84$ & 0.24 \\
\hline Never smoke & $0.57 \pm 0.06$ & & $71.19 \pm 1.79$ & \\
\hline \multicolumn{5}{|c|}{ Physical activity ( 30 minutes 3 times per week) } \\
\hline Yes & $0.59 \pm 0.05$ & 0.51 & $72.86 \pm 1.82$ & 0.03 \\
\hline No & $0.47 \pm 0.10$ & & $63.75 \pm 2.30$ & \\
\hline \multicolumn{5}{|l|}{ Comorbid disease } \\
\hline Stroke & $0.37 \pm 0.13$ & - & $0.68 \pm 0.03$ & - \\
\hline Diabetes & $0.58 \pm 0.09$ & & $0.71 \pm 0.03$ & \\
\hline Asthma & $0.68 \pm 0.09$ & & $0.70 \pm 0.03$ & \\
\hline ESRD & $0.68 \pm 0.14$ & & $0.70 \pm 0.07$ & \\
\hline Dyslipidemia & $0.79 \pm 0.10$ & & $0.83 \pm 0.07$ & \\
\hline Dyspepsia & $0.65 \pm 0.13$ & & $0.55 \pm 0.05$ & \\
\hline \multicolumn{5}{|c|}{ Length of antihypertension therapy (month) } \\
\hline$\leq 20$ & $0.58 \pm 0.06$ & 0.75 & $0.68 \pm 0.02$ & 0.26 \\
\hline$>20$ & $0.52 \pm 0.09$ & & $0.73 \pm 0.03$ & \\
\hline \multicolumn{5}{|l|}{ Therapy } \\
\hline CCB only & $0.50 \pm 0.07$ & 0.14 & $0.69 \pm 0.02$ & 0.17 \\
\hline Combination of CCB and ARB & $0.61 \pm 0.06$ & & $0.71 \pm 0.02$ & \\
\hline
\end{tabular}

This study has limitations. It included a small sample size $(n=83)$ due to the reluctance of most patients in participating in this project. Thus, certain variables could not be controlled. 
Table 3. QoL scores based on hypertension therapy (P-value shows the relationship between variables with the $\mathrm{QoL}$ ).

\begin{tabular}{lcccc}
\hline \multirow{2}{*}{ Therapy } & \multicolumn{2}{c}{ EQ5D5L } & \multicolumn{2}{c}{ EQVAS } \\
\cline { 2 - 5 } & Mean & $\boldsymbol{p}$-value & Mean & $\boldsymbol{p}$-value \\
\hline All therapies & $0.56 \pm 0.05$ & & $0.70 \pm 0.02$ & \\
CCB only & & & & \\
Amlodipine & $0.51 \pm 0.08$ & 0.92 & $0.68 \pm 0.02$ & 0.82 \\
Nifedipine & $0.38 \pm 0.53$ & & $0.70 \pm 0.05$ & \\
CCB + ARB therapy & & & & \\
Amlodipine and Candesartan & $0.61 \pm 0.08$ & 0.30 & $0.73 \pm 0.02$ & 0.15 \\
Amlodipine and Telmisartan & $0.20 \pm 0.71$ & & $0.80 \pm 0.00$ & \\
Amlodipine and Valsartan & $0.73 \pm 0.07$ & & $0.71 \pm 0.06$ & \\
Nifedipine and Candesartan & $0.89 \pm 0.04$ & & $0.75 \pm 0.06$ & \\
Nifedipine and Valsartan & $0.21 \pm 0.38$ & & $0.47 \pm 0.09$ & \\
\hline
\end{tabular}

\section{CONCLUSION}

It could be concluded that most of the adult hypertensive patients in this study indicated either slight or moderate problems in the area of pain/discomfort and anxiety/depression. Physical activity could increase the QoL of the hypertensive patients. The best QoL is specified to those who were treated with a combination of nifedipine (CCB) and candesartan (ARB).

\section{ABBREVIATIONS}

IC10-CM-I10: ICD-10-CM Diagnosis Code I10 is a code for essential (primary) hypertensive patients who do not have comorbid heart or kidney disease

\section{ACKNOWLEDGMENTS}

The authors wish to thank the hospital and investigators who participated in this study and Universitas Padjadjaran for facilitating the publication fee through Academic-Leadership Grant 2019.

\section{CONFLICT OF INTEREST}

Authors declare that they have no conflicts of interest.

\section{AUTHORS' CONTRIBUTIONS}

All authors have taken responsibility for the integrity of the work as a whole and have provided final approval of the version to be published. Jutti Levita conceptualized and designed the study, drafted the manuscript, and provided final approval of the version to be published. Dyah Aryani Perwitasari conceptualized and designed the study and provided final approval of the version to be published. Juwita Ramadhani collected the data, wrote the parts of the manuscript, and provided final approval of the version to be published. Mutakin Mutakin reviewed the project, analyzed the data, and provided final approval of the version to be published.

\section{REFERENCES}

Abraham HMA, White CM, White WB. The comparative efficacy and safety of the angiotensin receptor blockers in the management of hypertension and other cardiovascular diseases. Drug Saf 2015; 38(1):33-54.

Bădicu G. Physical activity and health-related quality of life in adults from Brașov, Romania. Educ Sci 2018; 8(2):52.
Bakas T, McLennon SM, Carpenter JS, Buelow JM, Otte JL, Hanna KM, Ellett ML, Hadler KA, Welch JL. Systematic review of healthrelated quality of life models. Health Qual Life Outcomes 2012; 10:134.

Barcenilla-Wong AL, Chen JS, Cross MJ, March LM. The impact of fracture incidence on health-related quality of life among communitybased postmenopausal women. J Osteoporosis 2015; 8 .

Bardage C, Isacson DG. Hypertension and health-related quality of life. an epidemiological study in Sweden. J Clin Epidemiol 2001; 54(2):172-81

Batey DM, Kaufmann PG, Raczynski JM, Hollis JF, Murphy JK, Rosner B, Corrigan SA, Rappaport NB, Danielson EM, Lasser NL, Kuhn CM. Stress management intervention for primary prevention of hypertension: detailed results from Phase I of trials of hypertension prevention (TOHP-I). Ann Epidemiol 2000; 10(1): 45-58.

Beckman KD. How to document and code for hypertensive diseases in ICD-10. Fam Pract Manag 2014; 21(2):5-9.

Black HR. Calcium channel blockers in the treatment of hypertension and prevention of cardiovascular disease: Results from major clinical trials. Clin Cornerstone 2004; 6(4):53-66.

Cernes R, Mashavi M, Zimlichman R. Differential clinical profile of candesartan compared to other angiotensin receptor blockers. Vasc Health Risk Manag 2011; 7:749-59.

Devlin NJ, Brooks R. EQ-5D and the EuroQol group: Past, present and future. Appl Health Econ Health Policy 2017; 15(2):127-37.

Fletcher A. Quality of life in the management of hypertension. Clin Exp Hypertens 1999; 21(5-6):961-72.

Grimm RH, Grandits GA Jr., Cutler JA, Stewart AL, McDonald RH, Svendsen K, Prineas RJ, Liebson PR. Relationships of quality-of-life measures to long-term lifestyle and drug treatment in the treatment of mild hypertension study. Arch Intern Med 1997; 157(6):638-48.

Hand C. Measuring health-related quality of life in adults with chronic conditions in primary care settings. Can Fam Physician 2016; 62(7):e375-83.

Herdman M, Gudex C, Lloyd A, Janssen M, Kind P, Parkin D, Bonsel G, Badia X. Development and preliminary testing of the new five-level version of EQ-5D (EQ-5D-5L). Qual Life Res 2011; 20(10): $1727-36$.

Izci F, Fındıklı E, Camkurt MA, Tuncel D, Şahin M. Impact of aggression, depression, and anxiety levels on quality of life in epilepsy patients. Neuropsychiatr Dis Treat 2016; 12:2595-603.

Kim KJ, Kim HY, Chun IA. Correlations between the sequelae of stroke and physical activity in Korean adult stroke patients. J Phys Ther Sci 2016; 28(6):1916-21.

Lee J, Kim Y. Association between green tea consumption and risk of stroke in middle-aged and older Korean men: the health examinees (HEXA) study. Prev Nutr Food Sci 2019; 24(1):24-31.

Lee JE, Kim K, Kim JS. Factors influencing quality of life in adult end-stage renal disease patients undergoing hemodialysis. J Nurs Res 2015; 23(3):181-8.

Ministry of Health of the Republic of Indonesia. National report on basic health research in 2018. Lembaga Penerbit Badan Penelitian dan Pengembangan, Indonesia, 2019.

Oza BB, Patel BM, Malhotra SD, Patel VJ. Health related quality of life in hypertensive patients in a tertiary care teaching hospital. J Assoc Physicians India 2014; 62(10):22-9.

Ozaki N, Nomura Y, Sobajima H, Kondo K, Oiso Y. Comparison of the effects of three angiotensin II receptor type 1 blockers on metabolic parameters in hypertensive patients with type 2 diabetes mellitus. Eur J Intern Med 2010; 21:236-9.

Purba FD, Hunfeld JAM, Iskandarsyah A, Fitriana TS, Sadarjoen SS, Ramos-Goñi JM, Passchier J, Busschbach JJV. The Indonesian EQ-5D5L value set. Pharmacoeconomics 2017; 35(11):1153-65.

Sari A. Kualitas hidup pasien hipertensi rawat jalan di Rumah Sakit PKU Muhammadiyah Bantul Yogyakarta dengan terapi kombinasi angiotensin reseptor blocker dan calcium channel blocker. Fakultas Farmasi Universitas Andalas, Padang, Indonesia, 2017. 
Setiawan D, Dusafitri A, Galistiani GF, van Asselt ADI, Postma MJ. Health-related quality of life of patients with HPV-related cancers in Indonesia. Value in Health Reg Issues 2018; 15:63-9.

Skevington SM. Qualities of life, educational level and human development: an international investigation of health. Soc Psychiatry Psychiatr Epidemiol 2010; 45(10):999-1009.

Staff PO. Correction: quality of life of the Indonesian general population: test-retest reliability and population norms of the EQ-5D-5L and WHOQOL-BREF. PloS One 2018; 13(8):e0203091.

Valkovic P, Minar M, Singliarova H, Harsany J, Hanakova M, Martinkova J, Benetin J. Pain in Parkinson's disease: a cross-sectional study of its prevalence, types, and relationship to depression and quality of life. PloS One 2015; 10(8):e0136541.

Wu L, Deng SB, She Q. Calcium channel blocker compared with angiotensin receptor blocker for patients with hypertension: a metaanalysis of randomized controlled trials. J Clin Hypertens (Greenwich) 2014; 16(11):838-45.

Zhang L, Guo X, Zhang J, Chen X, Zhou C, Ge D, Qian Y. Health-related quality of life among adults with and without hypertension: a population-based survey using EQ-5D in Shandong, China. Sci Rep 2017; $7(1): 14960$.
Zhu J, Wang W, Xiong Y, Cooper RS, Du Raza-Arvizu R, Cao G, Wang Y, Ji P, Bian R, Xu J. The association between tea consumption and hyperhomocysteine in Chinese hypertensive patients. Am J Hypertens 2019; 32(2):209-15.

How to cite this article:

Ramadhani J, Mutakin M, Perwitasari DA, Levita J. Quality of life of patients receiving a single or combination of calcium channel blocker-angiotensin receptor blocker: A cross-sectional study in West Java, Indonesia. J Appl Pharm Sci, 2020; 10(03):088-092. 